\title{
IMPLEMENTASI FUNGSI DAN TUGAS BAGIAN PEMERINTAHAN DAN OTONOMI DAERAH DI SEKRETARIAT DAERAH KOTA TANJUNGBALAI
}

\author{
Karoni Linda ${ }^{1)}$, Zaid Afif ${ }^{2)}$ \\ ${ }^{1)}$ Fakultas Hukum Universitas Asahan \\ ${ }^{2)}$ Fakultas Hukum Universitas Asahan \\ email: E-mail: dtm.zaid@ gmail.com
}

\begin{abstract}
ABSTRAK
Kewenangan Sekretariat Daerah Kota Tanjungbalai dalam menyelenggarakan sistem Pemerintahannya yaitu berwenang dalam memberikan hak asal usul, berwenang dalam memberikan lokal dalam berskala besar, berwenang yang ditugaskan Pemerintah Pusat hingga Pemerintah Daerah serta berwenang untuk melakukan tugas lainnya, yang diberikan dari Pemerintah Pusat hingga Pemerintahan Daerah, berdasarkan pada Hirarki Peraturan Perundang-Undangan. Maka oleh karena itu di dalam suatu penyelenggaraan Pemerintahan yang ada di wilayah Kota Tanjungbalai, Perwalkot Tanjungbalai No. 26 Tentang Kedudukan, Susunan Organisasi Tugas dan Fungsi Serta Tata Kerja Seretariat Daerah Kota Tanjungbalai, maka dalam hal ini dibagi ke dalam beberapa bagian diantaranya yaitu sebagai berikut : 1. Adanya suatu bidang sektor aparatur Pemerintahan dan pengawasan. 2. Adanya suatu bidang suatu sektor mengenai hukum. 3. Adanya suatu bidang di sektor politik. 4. Adanya suatu bidang sektor pertambangan dan energi serta parawisata.
\end{abstract}

Kata kunci: Implementasi, Fungsi, Tugas, Sekretariat, Daerah Tanjungbalai.

\section{ABSTRACT}

The authority of the Regional Secretariat of the City of Tanjungbalai in administering its Government system, namely the authority to grant rights of origin, authority to grant locales on a large scale, authorities assigned by the Central Government to Regional Governments and authorized to carry out other tasks, given from the Central Government to Regional Governments, based on in the Hierarchy of Laws and Regulations. So therefore in an existing government administration in the city of Tanjungbalai, Perwalkot Tanjungbalai No. 26 Regarding the Position, Organizational Structure of Tasks and Functions as well as the Work Procedure of the Regional Secretariat of the City of Tanjungbalai, in this case it is divided into several sections including the following: 1. There is a sector of the Government apparatus and supervision sector. 2. The existence of a sector regarding law. 3. There is a field in the political sector. 4. There is a mining and energy sector as well as tourism.

Keywords: Implementation, Function, Task, Secretariat, Tanjungbalai Area. 


\section{PENDAHULUAN}

Negara Indonesia merupakan negara yang sangat menjunjung tinggi nilai-nilai hukum yang berlaku pada suatu kehidupan masyarakat yang terdapat didalmnya, adapun mengenai tujuan atas kondusifnya suatu kehidupan di dalam kehidupan masyarakat, hal ini sebagaimana diutarakan di dalam Pasal 1 ayat (3) UUD Tahun 1945 yang dalam hal ini menyatakan bahwasannya Negara

Indonesia merupakan negara hukum". 1

Indonesia dinyatakan bahwa tergolong ke dalam daerah otonom, sebagaimana tertera tentang pada Pasal 18 ayat (1) UUD Tahun 1945, yang menyatakan bahwa : "Negara Kesatuan Republik Indonesia dibagi atas daerah-daerah provinsi dan daerah provinsi itu dibagi atas kabupaten dan kota, yang tiap-tiap provinsi, kabupaten, dan kota itu mempunyai pemerintahan daerah, yang diatur dengan undang-undang". 2

Maka oleh karena itu dengan adanya suatu ketentuan hukum yang berlaku dan juga mengikat, maka dalam hal ini Pemerintah Indonesia harus berupaya dalam melakukan pembentukan Peraturan PerundangUndangan dibawah UUD Tahun 1945, yang dalam hal ini sebagaimana Pemerintah telah menerbitkan UU No. 12 Tahun 2011 Tentang Pembentukan Peraturan Perundang-Undangan. Adapun mengenai hal

1 Rozali Abdullah, Pelaksanaan Otonomi Luas Dengan Pemilihan Kepala Daerah Secara Langsung (Jakarta: PT. Raja Grafindo Persada, 2005). hlm, 22.

${ }^{2}$ Solli Lubis, Perkembangan Garis

Politik Dan Perundang-Undangan Pemerintahan Daerah (Bandung: Alumni, 1983). hlm, 43. tersebut, maka dijelaskan lebih lanjut di dalam Pasal 7 ayat (1) UU No. 12 Tahun 2011 Tentang Pembentukan Peraturan Perundang-Undangan, yaitu : (1) Jenis dan hierarki Peraturan Perundang-Undangan terdiri atas : a. UUD Tahun 1945; b. TAP MPR; c. UU/PERPPU; d. PP; e. PERPRES; f. PERDA Provinsi; dan g. PERDA Kabupaten/Kota. ${ }^{3}$

Dalam hal ini Pemerintahan Republik Indonesia yang terbagi atas Pemerintah Daerah Provinsi, dan Kabupaten/Kota yang keseluruhannya bertugas untuk mengurus kebutuhan masyarakat di pemerintahan Indonesia.

Adapun kewenangan Sekretariat Daerah Kota Tanjungbalai dalam menyelenggarakan sistem Pemerintahannya yaitu berwenang dalam memberikan hak asal usul, berwenang dalam memberikan lokal dalam berskala besar, berwenang yang ditugaskan Pemerintah Pusat hingga Pemerintah Daerah serta berwenang untuk melakukan tugas lainnya,yangdiberikandari

Pemerintah Pusat hingga Pemerintahan Daerah, berdasarkan pada Hirarki Peraturan PerundangUndangan.

Maka oleh karena itu di dalam suatu penyelenggaraan Pemerintahan yang ada di wilayah Kota Tanjungbalai, Perwalkot Tanjungbalai No. 26 Tentang Kedudukan, Susunan Organisasi Tugas dan Fungsi Serta Tata Kerja Seretariat Daerah Kota Tanjungbalai, maka dalam hal ini dibagi ke dalam beberapa bagian diantaranya yaitu sebagai berikut $: 1$.

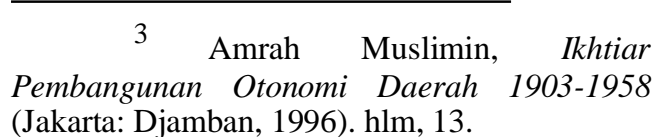


Adanya suatu bidang yang dalam hal ini berada di sektor aparatur Pemerintahan dan pengawasan. 2 . Adanya suatu bidang yang dalam hal ini berada di suatu sektor mengenai hukum. 3. Adanya suatu bidang sektor politik. 4. Adanya suatu bidang sektor pertambangan dan energi serta parawisata.

Berdasarkan dari hasil penjelasan yang diuraikan di dalam

latar belakang diatas, dalam melakukan dan mengadakan suatu penelitian hukum dengan judul

Implementasi Fungsi Dan Tugas Bagian Pemerintahan Dan Otonomi Daerah Di Sekretariat Daerah Kota Tanjungbalai.

\section{METODE PENELITIAN Metode} penelitian merupakan

metode ilmiah yang digunakan peneliti untuk memperoleh data yang diinginkan. "Metode ilmiah berarti bahwa kegiatan yang dilakukan didasarkan pada metode ilmiah yang terbukti. Untuk memastikan penemuan kebenaran ilmiah, metode penelitian menyediakan metode operasi yang sangat tepat dan kondisi yang sangat keras. Artinya, metode penelitian tidak hanya bertujuan

untuk memberikan kesempatan sebesar-besarnya bagi pengetahuan objektif tentang kebenaran, tetapi juga untuk menjaga agar ilmu dan perkembangannya memiliki nilai keilmuan yang tinggi.

Jenis penelitian Dalam suatu penelitian ini pendekatan empiris yang digunakan untuk menganalisis hukum yang dipandang sebagai perilaku masyarakat yang terpola dalam kehidupan masyarakat yang selalu berinteraksi dan berhubungan dalam aspek sosial. $^{4}$ Dalam melaksanakan pendekatan yuridis empiris ini, dengan metode deduktif dapat menggambarkan ketentuan mengenai Implementasi Fungsi Dan Tugas Bagian Pemerintahan Dan Otonomi Daerah Di Sekretariat

Daerah Kota Tanjungbalai. Sedangkan metode induktif adalah data yang diperoleh dari hasil penelitian lapangan untuk menarik kesimpulan umum.

Lokasi Penelitian Lokasi penelitian dilakukan di kota tanjung balai yaitu di sekretariat Kota

Tanjungbalai mengingat objek penelitian yang akan dilakukan terkait dengan Implementasi Fungsi Dan Tugas Bagian Pemerintahan Dan Otonomi Daerah Di Sekretariat Daerah Kota Tanjungbalai, sehingga benar-benar memudahkan peneliti untuk mendapatkan informasi atau data terkait Implementasi Fungsi Dan Tugas Bagian Pemerintahan Dan Otonomi Daerah Di Sekretariat Daerah Kota Tanjungbalai. Sumber data Pendekatan yang digunakan adalah pendekatan empiris, sehingga pendekatan pengumpulan data yang sesuai untuk penulisan penelitian ini.

Selain berupa peraturan perundang-undangan, data sekunder juga dapat berupa pendapat dari para ahli yang ahli di bidang tersebut, yang disampaikan dalam berbagai literatur baik dari buku, teks ilmiah, laporan penelitian, media massa dan lain-lain.

. Data sekunder juga dapat dibedakan menjadi 3 (tiga) bagian yaitu Penulis dalam melakukan penelitian untuk mengabil data penelitian

4 Bambang Sunggono, Metodologi Penelitian Hukum, ed. PT Raja Grafindo Persada (Jakarta, n.d.). hlm 43 
menggunakan sumber data, dimana sumber data yang digunakan di penelitian ini didapat dari sumber data primer dan sumber data sekunder. Dengan menggunakan dua macam bahan hukum yang meliputi Sumber data primer yaitu sumber data yang diperoleh secara langsung dari sumber pertama yang terkait dengan permasalahan yang akan dibahas. 5 Sumber data yang diperoleh dari lapangan dengan wawancara berbagai pihak yang menyangkut terhadap permasalahan dalam penelitian.

Sumber data sekunder yaitu bahan hukum yang diperoleh Buku sebagai salah satu bahan hukum merupakan berbagai buku yang berkaitan dengan pembahasan penelitian yang dilakuan oleh penulis mengenai bahan hukum yang terdiri dari: a. Merupakan hasil dari bahan pustaka ataupun dari literatur buku; b. Bahan yang berasal dari berbagai hasil seminar dan tulisan artikel yang ada di internet sebagai bahan hukum yang berhubungan dengan penelitian serta pembahasan dalam penulisan penelitian in. c. Selanjutnya mengambil dari berbagai bahan hukum dari hasil yang dilakukan penelitian sebelumnya.

Teknik pengumpulan data Penelitian yang dilakukan penulis menggunakan empiris tentunya harus disesuaikan dengan tata cara atau teknik penulisan ini dengan mempergunakan teknik pengumpulan data memakai sumber bahan hukum.

Dalam mengolah data yang dibutuhkan, dilakukan wawancara dengan responden secara langsung

5 Amiruddin dan Zainal Asikin, Pengantar Metode Penelitian Hukum (Jakarta: Kencana, 2006). hlm, 30. mengenai Implementasi Fungsi Dan Tugas Bagian Pemerintahan Dan Otonomi Daerah Di Sekretariat Daerah Kota Tanjungbalai.

Metode ini digunakan dengan melalui suatu pengumpulan suatu data-data yang ada dilapangan dengan memanfaatkan ketersediaan waktu yang ada agar terjawab pokok permasalahan yang diangkat di dalam suatu penelitian ini dengan melakukan suatu pemantauan secara langsung Implementasi Fungsi Dan Tugas Bagian Pemerintahan Dan Otonomi Daerah Di Sekretariat

Daerah Kota Tanjungbalai. "Pemahaman terhadap fungsi pengawasan DPRD terhadap implementasi kebijakan Daerah, diperoleh dari teori yang ada

sebelumnya namun disesuaikan dengan peraturan Perundangundangan yang berlaku pada khususnya UndangUndang tentang otonomi Daerah". 6

\section{HASIL DAN PEMBAHASAN Penyelenggaraan Fungsi Dan Tugas Bagian Pemerintahan Dan Otonomi Daerah Seketariat Daerah}

Dalammenyelenggarakan

suatu penyelenggaraan Pemerintah Daerah, dalam hal ini didasari pada ketentuan hukum yang diatur di dalam Pasal 18 UUD Tahun 1945, yang mana menegaskan bahwasannya Pemerintah Daerah ialah merupakan

6 Junindra Martua. Rahmat, "Kolaborasi Kinerja Dewan Perwakilan Rakyat Daerah (DPRD) Dan Kepala Daerah Kota Tanjungbalai Di Tinjau Dari Undang-Undang Nomor 23 Tahun 2014 Tentang Pemerintahan Daerah," Citra Justicia dan Dinamika Kemasyarakatan Vol 20, No (2019): 1-13. 
suatu unsur yang paling utama untuk menyelenggarakan atas suatu Pemerintahan Daerah. "Sebagai salah satu instrumen dalam praktik penyelenggaraan negara dan berbagai upaya pembangunan di dalamnya, birokrasi mempunyai peranan penting di dalam kehidupan masyarakat. Di Indonesia yang masyarakatnya sedang terus menrus melakukan perubahan melalui berbagai aktivitas positif yang konstruktif"?

Mengenai hal ini adapun tujuan dari adanya suatu penyelenggaraan Pemerintahan Daerah seharusnya dapat senantiasa dapat lebih bersinergi dan juga dapat nantinya mendorong atas demi terwujudnya suatu cita-cita bangsa agar dapat terwujudnya suatu keadilan dan juga suatu kemakmuran dengan berlandaskan pada Pancasila dan UUD Tahun 1945.

Adapun mengenai suatu gambaran atas kondisi dilapangan secara fakta, maka Sekretariat Daerah di wilayah Kota Tanjungbalai, sejak tahun 2005 hingga sampai dengan Tahun 2010, memiliki suatu kebijakan terhadap suatu penyelenggaraan Pemerintahan secara nasional, yang mana diatur secara jelas di dalam UU No. 23 Tahun 2014 Tentang Pemerintahan Daerah. "Pemberian otonomi kepada pemerintahan untuk mengurus secara merata kepada daerahdaerah yang belum sejahtera serta perlu diarahkan untuk mempercepat pembangunan dan

7 Junindra Martua Wirda Eka Putri, Rahmat, "Peranan Peradilan Tata Usaha Negara Dalam Menciptakan Pemerintahan Yang Baik Ditinjau Dari Segi Hukum Administrasi Negara," Jurnal Pionir LPPM Universitas Asahan Vol. 5 NO.4 JuliDesember 20195 (2019): 343-348. terwujudnya

kesejahteraan masyarakat melalui peningkatan

pelayanan secara adil dan bersinambungan sebagai bentuk pelayanan, pemberdayaan dengan sesuai ketentuan dan peran serta masyarakat". 8

Maka oleh karena itu dengan adanya suatu penyelenggaraan daripada Pemerintahan Daerah, maka dalam hal ini dapat dibagi menjadi ke dalam berbagai macam bagian, yang mana diantaranya ialah : a. Bidang Pemerintahan Umum. b. Bidang Ekonomi c. Bidang Pembangunan. d. Bidang Kesejahteraan Sosial.

Maka oleh karena itu, dengan berdasarkan pada suatu kekuhususan dalam penyelenggaraan Pemerintahan Dearah yang secara umum yang ada di Kota Tanjungbalai, maka dalam hal ini dapat dibagi menjadi beberapa bagian, diantaranya yaitu : 1 . Adanya suatu bidang yang dalam hal ini

berada di sektor aparatur Pemerintahan dan pengawasan, yang mana meliputi : a. Sektor yang menangani suatu permasalahan di bidang administrasi Pemerintahan Umum. b. Sektor yang menangani suatu permasalahan di bidang administrasi Pemerintahan Desa. c. Sektor yang menagangi administrasi Pemerintahan Kependudukan dan Pencatatan Sipil. d. Sektor yang menagangi administrasi

Pendayagunaan Aparatur dan pelaksanaan suatu pengawasan. 2 . Adanya suatu bidang yang dalam hal ini berada di sektor hukum 3. Adanya

8 Wulandari, Fika, Zaid Afif, "Pelaksanaan Tugas Dan Fungsi Dewan

Perwakilan Rakyat Daerah Kota Tanjungbalai Ditinjau Bari Tata Tertib Nomor 1 Tahun 2018," Jurnal Tectum, Universitas Asahan. 1, no. 1 (2019): 99-104. 
ISSN 1411-0717 (CETAK)

suatu bidang yang dalam hal ini berada di sektor politik. 4. Adanya suatu bidang yang dalam hal ini berada di sektor pertambangan dan energi serta parawisata. 5. Adanya suatu bidang yang dalam hal ini

berada di sektor aparatur Pemerintahan dan pengawasan.

Dalam hal ini dengan berdasrkan seiringnya waktu, maka dengan sesuai suatu pengaturan yang terdapat di dalam UU No. 23 Tahun 2014 Tentang Pemerintahan Daerah, maka adapun yang menjadi kewenangannya ialah mengenai luas daripada daerah tersebut.

Adapun dalam hal ini untuk dapat mengatur tentang rumah tangga Sumber terhadap daerah wilayah Kota

Tanjungbalai, maka haruslah mendefnitifkan suatu keseriusan di dalam suatu Kecamatan yang mana dengan cara melalui Peraturan Walikota Tanjungbalai No. 26 Tahun 2016 Tentang Kedudukan, Susunan Oraganisasi Tugas dan Fungsi Serta Tata Kerja Sekretariat Daerah Kota Tanjungbalai, maka oleh karena itu haruslah didasari pada suatu penanggapan yang dapat ditanggapi secara administratif, terutama yang ada di wilayah Kota Tanjungbalai, yang dalam hal ini memiliki 6 Kecamatan yang tersebar di wilayah Kota Tanjungbalai, yang diantaranya yaitu :

Tabel 4. Nama-Nama Kecamatan, Luas Wilayah dan Jumlah Penduduk di Kota Tanjunbalai

\begin{tabular}{|c|c|}
\hline \multicolumn{1}{|c|}{ Kota Tanjunbalai } \\
\hline No & Kecamatan \\
\hline 1. & Datuk Bandar \\
\hline 2. & Datuk Bandar Timur \\
\hline 3. & Tanjungbalai Selatan \\
\hline 4. & Tanjungbalai Utara \\
\hline 5. & Teluk Nibung \\
\hline 6. & Sei Tualang Raso \\
\hline Sumber : Kantor Walikota Tanjungbalai 2020 \\
\hline
\end{tabular}

: Kantor Walikota Tanjungbalai 2020

Maka oleh karena itu setelah adanya suatu penyeimbangan atas adanya suatu aspek yang secara

geografi, demografi, jumlah pendudukserta adanya suatu aspek di dalam pendekatan dalam hal pelayanan publik, maka dalam hal ini haruslah mengacu pada suatu ketentuan yang ada di dalam UU No. 23 Tahun 2014 Tentang Pemerintahan Daerah jo. PP No. 18 Tahun 2016 Tentang Perangkat Daerah, yang dalam hal ini dilakukannya suatu

penataan serta adanya suatu restrukturisasi atas suatu organisasi di dalam suatu Pemerintahan Daerah.

Maka oleh karena itu dengan didasari pada suatu pendapat yang mana di dalam suatu organisasi Pemerintahan Daerah yang ada di Kota Tanjungbalai, maka haruslah dilakukan suatu penataan ulang atas adanya suatu organisasi Pemerintahan yang ada di Kecamatan.

Adapun dalam hal ini jika dilihat dari adanya suatu ketentuan 
yang telah dikelaurkan di dalam Peraturan Daerah Kota Tanjungbalai No. 6 Tahun 2016 Tentang Pembentukan Perangkat Daerah Kota Tanjungbalai, maka dengan hal ini

haruslah didasari pada suatu ketentuan yang ada di dalam Peraturan Daerah yang dimaksud, sehingga nantinya suatu wilayah di

dalam administrasi di dalam Pemerintahan Kota Tanjungbalai dapat berjalan secara spesifik atas 6 wilayah yang dibawah naungan

daripada Pemerintahan Kota Tanjungbalai.

Adanya suatu bidang yang dalam hal ini berada di sektor aparatur Pemerintahan dan pengawasan

Mengenai suatu upaya untuk dapat mewujudkan suatu Pemerintahan yang bersih dan juga berwibawa, maka dalam hal ini selama dalam waktu yang telah

ditentukan, maka peningkatan terhadap suatu kuantitas atas sumber daya aparatur yang ada di Kota Tanjungbalai. Adapun dalam hal ini ASN yang ada di Kota Tanjungbalai mencapai 1809 orang.

Maka adapun suatu upaya dalam pengembangan atas SDM yang ada di ruang lingkup Pemerintahan Daerah Kota Tanjungbalai, maka haruslah dapat mempersiapkan diri untuk dapat menambah aparatur sipil yang bekerja di ruang lingkup Pemerintahan Kota Tanjungbalai.

Maka adapun dalam program penambahan SDM terhadap ASN yang ada di Kota Tanjungbalai dalam hal ini sangtalah memiliki tujuannya yaitu kedepannya demi mewujudkan suatu Pemerintahan Daerah yang baik, atas dalam melaksanakan suatu desentralisasi terhadap suatu kewenangan dengan berdasarkan pada UU No. 23 Tahun 2014 Tentang Pemerintahan Daerah, yang mana tujuannya yaitu agar nantinya dapat melaksanakan tugas Pemerintahan dengan baik dan dapat melaksanakan atas suatu pembangunan dan juga pembinaan terhadap kemasyarakatan dengan berorientasi terhadap suatu perbaikan mutu dan juga kepuasan dalam melayani masyarakat.

Maka oleh karena itu di dalam suatu kelembagaan di Pemerintahan DaerahKotaTannjungbalai,

bahwasannya sangat banyaklah mengalami suatu perubahan, yang dimana perubahan tersebut ialah perubahan secara fundamental yang mana berasal dari sebagi hasil restrukturisasi atas organisasi yang ada di PerUU. Maka untuk itu dengan adanya suatu restrukturisasi di dalam suatupenyelenggaraanatas

Pemerintahan Daerah Kota Tanjungbalai, maka harus didasari suatu pertimbangan-pertimbangan yaitu : a. Kewenangan yang dimiliki oleh Pemerintah Daerah Kota Tanjungbalai. b. Terdapat adanya suatu karakteristik serta potensi dan juga harus adanya suatu pertimbangan di dalam kebutuhan daerah. c. Terdapat adanya suatu kemampuan keuangan daerah. d. Adanya suatu ketersediaan atas adanya suatu sumber daya aparatur yang ada di Kota Tanjungbalai. e. Adanya suatu pengembangan terhadap suatu pengembangan atas pola kerjasama antar daerah dan/atau dengan para pihak ketiga.

Kendala Bagian Pemerintahan Dan Otonomi Daerah Di SekretariatDaerahKota Tanjungbalai Dalam Menyelenggarakan Fungsi Dan 


\section{Tugas Dalam Menyelenggarakan Fungsi Dan Tugasnya}

Dalam hal ini adapun faktor yang menjadi penghambat dalam menjalankan suatu kinerja Pemerintahan Daerah Kota Tanbjungbalai, maka haruslah dapat melaksanakan fungsi di dalam Pemerintahan di Kota Tanjungbalai, yang mana juga dalam menjalankan kinerja atas penyelenggaraan Pemerintahan Daerah Kota Tanjungbalai, terdapat beberapa faktor penghambat, diantaranya yaitu $: 1$. Adanya manusia yang dalam hal ini dalam suatu pelaksanaannya yang kurang profesional/kurang berkualitas 2. Adanya suatu keuangan daerah di Pemerintah Kota Tanjungbalai yang sangatlah kurang memadai. 3 .

Adanya suatu saranadan
prasarana/peralatan yang dalam hal
ini kurang tersedia. 4. Terdapat
adanya suatu organisasi dan juga
manajemen yang dalam hal ini kurang
baik. 1. Adanya manusia yang dalam
hal ini dalam suatu
pelaksanaannyayangkurang
profesional/kurang berkualitas.
Dalam melaksanakan tugas untuk
menyelenggarakanPemerintahan

Daerah di Pemerintah Kota Tanjungbalai, maka dalam hal ini bahwasannya para pekerja yang bekrja di Pemerintahan Daerah Kota Tanjungbalai tidak begitu optimal dalam melaksanakan fungsinya untuk menjalankan Pemerintahan Daerah Kota Tanjungbalai, yang mana dikarenakan kurangnya kualitas kemampuan ilmu pengetahuan para pekerja yang ada di ruang lingkup

Pemerintah Daerah Kota Tanjungbalai. 2. Adanya suatu keuangan daerah di Pemerintah Kota Tanjungbalai yang sangatlah kurang memadai. Dalam melaksanakan suatu tugas untuk menyelenggarakan Pemerintahan Daerah atas suatu urusan rumah tangga, maka dalam hal ini sangatlah membutuhkan dana dan juga uang,

Maka oleh karena itu dengan

demikian, Pemerintah Kota Tanjungbalai dalam menjalankan urusan rumah tangganya, sangat minim dalam masalah pembiaayn anggaran untuk menyelenggarakan

Pemerintahan Daerah Kota Tanjungbalai, sebab keuangan kas

Pemerintah Daerah Kota Tanjunhgbalai kurang memadai sehingga masih memerlukan bantuan dari pihak manapun. 1. Adanya suatu sarana dan prasarana/peralatan yang dalam hal ini kurang tersedia. Adapun dalam hal ini sarana dan juga prasarana yang dimiliki Pemerintah Daerah Kota Tanjngbalai pada saat ini kurang tersedia, karena di dalam

penyelenggaraan Pemerintahan Daerah Kota Tanjungbalai, masih banyak ketidak tersedianya sarana dan juga prasarana yang ada di wilayah Kota Tanjungbalai, sehingga hal ini menjadi kendala atas

penyelenggaraan Pemerintahan Daerah Kota Tanjungbalai dapat berjalan dengan baik. 2. Terdapat adanya suatu organisasi dan juga manajemen yang dalam hal ini kurang baik. Dalam hal ini faktor ynag juga dapat mempengaruhi (menghambat) suatu efektivitas di dalam suatu penyelenggaraan pada bidang umum di wilayah Kota Tanjungbalai ialah berupa faktor organisasi dan juga mengenai manajemen. 


\section{KESIMPULAN}

Dari adanya suatu penjelasan dan juga pemaparan yang telah dibahas di dalam suatu penelitian hukum ini yang diteliti oleh peneliti, maka oleh karena itu di dalam suatu Pembahasan pada penelitian hukum ini, maka dalam hal ini dapat ditarik daripada suatu kesimpulan di dalam penelitian hukum ini yaitu : 1. Dalam menyelenggarakan suatu penyelenggaraan Pemerintah Daerah, dalam hal ini didasari pada ketentuan hukum yang diatur di dalam Pasal 18 UUD Tahun 1945, yang mana menegaskan bahwasannya Pemerintah Daerah ialah merupakan suatu unsur yang paling utama untuk menyelenggarakan atas suatu Pemerintahan Daerah. Mengenai hal ini adapun tujuan dari adanya suatu penyelenggaraan Pemerintahan Daerah seharusnya dapat senantiasa dapat lebih bersinergi dan juga dapat nantinya mendorong atas demi terwujudnya suatu cita-cita bangsa agar dapat terwujudnya suatu keadilan dan juga suatu kemakmuran dengan berlandaskan pada Pancasila dan UUD Tahun 1945. Adapun mengenai

suatu gambaran atas kondisi dilapangan secara fakta, maka Sekretariat Daerah di wilayah Kota Tanjungbalai, sejak tahun 2005 hingga sampai dengan Tahun 2010, memiliki suatu kebijakan terhadap suatu penyelenggaraan Pemerintahan secara nasional, yang mana diatur secara jelas dindalam UU No. 23 Tahun 2014 Tentang Pemerintahan Daerah. 2. Dalam hal ini adapun faktor yang menjadi penghambat dalam menjalankan suatu kinerja

Pemerintahan Daerah Kota Tanbjungbalai, maka haruslah dapat melaksanakan fungsi di dalam
Pemerintahan di Kota Tanjungbalai, yang mana juga dalam menjalankan kinerja atas penyelenggaraan Pemerintahan Daerah Kota Tanjungbalai, terdapat beberapa faktor penghambat, diantaranya yaitu : 1. Adanya manusia yang dalam hal ini dalam suatu pelaksanaannya yang kurang profesional/kurang berkualitas. 2. Adanya suatu keuangan daerah di Pemerintah Kota Tanjungbalai yang sangatlah kurang memadai. 3. Adanya suatu saranadan prasarana/peralatan yang dalam hal ini kurang tersedia. 4. Terdapat adanya suatu organisasi dan juga manajemen yang dalam hal ini kurang baik. Berdasarkan daripada hasil yang dijelaskan dalam kesimpulan pada penelitian hukum ini secara lebih jelas yang dipaparkan diatas, maka untuk itu dalam hal ini peneliti dalam melakukan penelitian hukum ini menyampaikan adanya suatu saran terkait di dalam penelitian hukum ini, yang dalam hal ini meliputi : 1. Seharusnya dalam penyelenggaraan fungsi dan juga tugas di dalam Pemerintahan Daerah Kota Tanungbalai dapat lebih melakukan suatu inovasi-iniovasi yang lebih baik lagi sehingga

kedepannya kebijakan-kebijakan yang dibuat untuk memajukan sistem pemerintahan daerah di Kota Tanjungbalai dapat lebih maksimla dan tidak terjadi tumpang tindih. 2 . Sebaiknya pihak Pemerintah Daerah Kota Tanjungbalai dapat melakukan inovasi yang gemilang untuk dapat mengurangi meminimalisir atas suatu kendala-kendalayangdapat

mempengaruhi kinerja sistem Pemerintahan Daerah di Kota Tanjungbalai. 


\section{DAFTAR PUSTAKA}

Buku

Amrah Muslimin. Ikhtiar Pembangunan Otonomi Daerah 1903-1958. Jakarta: Djamban, 1996.

Asikin, Amiruddin dan Zainal. Pengantar Metode Penelitian Hukum. Jakarta: Kencana, 2006.

Bambang Sunggono. Metodologi Penelitian Hukum. Edited by PT Raja Grafindo Persada. Jakarta, n.d.

Hadari Nawawi. Metode Penelitian Sosial. Edited by Gajah Mada Press. Yogyakarta, 1985.

Rahmat, Junindra Martua. "Kolaborasi Kinerja Dewan Perwakilan Rakyat Daerah (DPRD) Dan Kepala Daerah Kota Tanjungbalai Di Tinjau Dari Undang-Undang Nomor 23 Tahun 2014 Tentang Pemerintahan Daerah." Citra Justicia dan Dinamika Kemasyarakatan Vol 20, No (2019): 1-13.

Rozali Abdullah. Pelaksanaan Otonomi Luas Dengan Pemilihan Kepala Daerah Secara Langsung. Jakarta: PT. Raja Grafindo Persada, 2005.

Solli Lubis. Perkembangan Garis Politik Dan PerundangUndangan Pemerintahan Daerah. Bandung: Alumni, 1983.

Wirda Eka Putri, Rahmat, Junindra

Martua. "PERANAN PERADILAN TATA USAHA

NEGARA

DALAM

MENCIPTAKAN

PEMERINTAHAN YANG

BAIK DITINJAU DARI

SEGI

HUKUM
ADMINISTRASI NEGARA." Jurnal Pionir LPPM Universitas Asahan Vol. 5 No.4 Juli-Desember 20195 (2019): 343-348.

Wulandari, Fika, Zaid Afif, Fakultas Hukum, Universitas Asahan, Sumatera Utara, and Jurnal Tectum. "Pelaksanaan Tugas Dan Fungsi Dewan Perwakilan Rakyat Daerah Kota Tanjungbalai Ditinjau Bari Tata Tertib Nomor 1 Tahun 2018." Jurnal Tectum, Universitas Asahan. 1, no. 1 (2019): 99-104. 